Meta

Journal des traducteurs

Translators' Journal

\title{
Self Correction in Translation Courses: A Methodological Tool
}

\section{Isabel Mizón M. et M. Isabel Diéguez M.}

Volume 41, numéro 1, mars 1996

Le(s) processus de traduction / Translation Process(es)

URI : https://id.erudit.org/iderudit/003654ar

DOI : https://doi.org/10.7202/003654ar

Aller au sommaire du numéro

Éditeur(s)

Les Presses de l'Université de Montréal

ISSN

0026-0452 (imprimé)

1492-1421 (numérique)

Découvrir la revue

Citer cet article

Mizón M., M. I. \& Diéguez M., M. I. (1996). Self Correction in Translation Courses: A Methodological Tool. Meta, 41(1), 75-83.

https://doi.org/10.7202/003654ar

\section{Résumé de l'article}

Cet article vise trois objectifs 1) fournir une base psycholinguistique des processus pédagogiques en didactique de la traduction, particulièrement pour la technique d'autocorrection, 2) présenter des exemples concrets

d'auto-correction et les discuter à la lumière de ces arrière-plans théoriques, et 3) suggérer des implications pratiques de cette technique dans la formation des traducteurs. 


\title{
SELF CORRECTION IN TRANSLATION COURSES: A METHODOLOGICAL TOOL
}

\author{
M. Isabel Mrzón M. ANd M. Isabel Diéguez M. \\ Pontificia Universidad Católica de Chile, Santiago, Chile
}

\begin{abstract}
Résumé
Cet article vise trois objectifs 1) fournir une base psycholinguistique des processus pédagogiques en didactique de la traduction, particulièrement pour la technique d'autocorrection, 2) présenter des exemples concrets d'auto-correction et les discuter à la lumière de ces arrière-plans théoriques, et 3) suggérer des implications pratiques de cette technique dans la formation des traducteurs.
\end{abstract}

\begin{abstract}
The article has three basic objectives: 1) to provide a psycholinguistic grounding of pedagogical procedures in the didactics of translation, specifically for the technique of selfcorrection, 2) to provide concrete examples of self-correction and discuss them in light of this theoretical background, and 3) to suggest practical implications of this technique in the field of translator training.
\end{abstract}

\section{INTRODUCTION}

Our interest in this presentation is to explore a new integrated approach to understanding translation tasks in regard to the training of professional translators. We think this approach can be useful both to evaluate the quality of foreign language competence needed in training professional translators, and to provide adequate pedagogical procedures for the development of fast strategic translation specific skills. We will look at translation performance from the point of view of psycholinguistics and, from there, we will proceed to discuss the systematic monitoring of the technique of self-correction.

Self-correction, a normal stage in translation activities, deserves to be analysed in connection with the mental processes underlying translation. We believe that the examination of this stage in the light of a model for the whole process of translation performance, is useful in establishing useful pedagogical procedures. In our view, through the activity of self-correction, the student becomes involved in restructuring his language and knowledge competences. The associated techniques of revising, rephrasing and editing a provisional target text may become crucial in the gradual development of translation competence as such.

Moreover, we contend that the pedagogical exploitation of the technique of selfcorrection may facilitate the achievement of autonomous problem-solving ability that the future professional translator will later need. By pedagogical monitoring the revision skills of students, they can be nurtured and guided on how to reflect on their decisions, to make the most of their individual resources and to assess and guide their overall performance by responding to outcome feedback. We, therefore, see self-correction as structuring a task domain for acquiring and exercising language and translation competence together with the ability to think critically and the ability to act on the results of such thought.

In the text that follows we will refer in more detail to the psycholinguistic model of the translation process. We will interpret and develop Königs's model to illustrate the 
procedure of self-correction and we will also discuss the role of self-correction as it is applied in the School of Translation at the Pontificia Universidad Católica de Chile.

\section{TRANSLATION PROCESS AND SELF-CORRECTION}

An important contribution in our undertaking is Königs's model of the translation process. This model, based on verbal protocols, has provided data on the mental operations that control the decision-making processes of natural translators. Though Königs does not concern himself with translation pedagogy, his model of the process has been very useful for our purposes. In the next few paragraphs, we will describe the translation process as the results obtained by Königs suggest.

Faced with a source text, the translator's ad hoc block automatically triggers stored routines to handle the task. The ad hoc block corresponds to the subject's internalized experience perceived relevant to a translation task. This ad hoc block contains knowledge resources of various kinds such as, automatized linguistic structures in L1/L2, a kit of translation tools with problem-solving routines, and general conceptual information. These knowledge resources, instantaneously activated, according to Königs, handle unproblematic linguistic-semantic configurations and guide the text-building operation implied in the accomplishment of the translation task. In a first attempt, the ad hoc block controls execution, allowing the translator to generate a provisional translation without any delay. The ad hoc block takes the translator as far as possible in his intent to produce a meaningful target text. As a result of deficiencies in the ad hoc block, the meaningfulness produced, however, may not correspond to that intended by the sender of the original message. Distortions of meaning, inaccuracy, conceptual inconsistencies, and lack of coherence may occur inadvertently.

In the process of applying the ad hoc block then, the translator becomes inevitably aware of problematic configurations. These activate what Königs calls a residual block. This block is strategically and attentionally controlled, and its function is to solve the difficulties perceived. Such difficulties may be identified at different stages of the operation (comprehension, interpretation, writing); they can involve different kinds of competences (procedural, linguistic, knowledge, cultural-pragmatic), and they may need to be dealt with at message units of various sizes (word, phrase, clause, sentence, text). The residual block can promptly suggest pre-programmed tentative solutions for the problems perceived. After a pause, the operation resumes, or failing to handle the difficulty with the resources at hand, the residual block can help identify, analyse and assess the importance and specific nature of the problem in order to guide the search for external means. The residual block can also help the translator to decide on the processing that will be required to transform the external, newly acquired information into relevant solutions that are also stylistically adequate. The residual block may contain knowledge of unfamiliar or ambiguous grammatical or rhetorical configurations, vague and limited conceptual background knowledge, knowledge that hints at specific, yet unknown terminology, and all information that may signal the need for conscious revision and re-elaboration. Extralinguistic information related to the text (author, subject matter, intention, addressee) also belongs to the residual block. It is clear from this account that this block plays an important role in improving revision skills.

The translator draws upon the ad hoc and the residual blocks to produce a provisional translation, this draft then becomes a kind of problem space on which the trainee projects his different competences, fitting and articulating the resources he has found relevant in the environment. By manipulating the outcome versions through succesive supervised revisions and corrections, he assesses the efficiency and productivity of the solutions contemplated and finally arrives at a satisfactory target text. 
The explanation of translation performance offered by Königs, and the corresponding awareness of the role of the two blocks in the process of translation, can provide the basis for a principled methodology for the translation class and help to exploit the technique of self-correction in a much wider frame.

\section{THE TECHNIQUE OF SELF-CORRECTION AS A METHODOLOGICAL TOOL}

We agree with the authors that consider translation basically a natural process of a very complex cognitive and linguistic nature (Lörscher 1991; Bialystok (Ed.) 1991; Toury 1986). It is natural because, according to these researchers, different degrees of $\mathrm{L} 1$ and L2 proficiency spontaneously trigger the readiness for undertaking translation tasks in a natural fashion. It is complex, for it involves the integration of information resulting from different interacting linguistic-cognitive subprocesses, such as decoding, understanding, interpreting and writing. Each of these subprocesses produces either psychological or linguistic representations which are put together and made to cohere for the execution of the translation task. It is evident that, although linguistically stimulated and data-driven, comprehension results in a psychological product, a mental representation, whereas psychologically stimulated and cognitively driven, interpretation and translation result in an external linguistic product, a text. It is also true that in reading, scripts, schemata, and other knowledge contents of memory often guide the reader's expectations and thus indirectly determine inference processes and orient choices of lexical meaning. Similarly, those parts of the text already translated and externalized indirectly constrain the choices in the wording of what follows.

What is specific to translation then, is that when we read the source text, we do so with the overall goal of coming up with a text in the target language, and while we are writing that target text, we do so in full awareness that the choice of forms is controlled by the mental image created by our interpretation of forms in the source text. In this sense, the operation is like that of filling a template. Translation needs very efficient $\operatorname{cog}$ nitive planning and coordination to ensure accommodation and transformation of very disparate data into the meaningful evolving forms of the target text. In other words, translation makes exceptional demands on the working memory because at each stage the outcomes may indirectly signal the need to recycle previous stages, to introduce corrections or to adjust results.

As we previously stated, the present approach entails conceiving translation as a complex process with a number of simultaneous interrelated cognitive subprocesses underlying it. Basically, decoding, understanding, interpreting and writing are all involved in translation. These operations make simultaneous demands on a common information base: language knowledge, world knowledge and knowledge of culture-specific communicative practices. When the operations mentioned above, each with its own goal, are executed simultaneously or in close coordination, as is the case in the completion of translation tasks, they all compete for access to that shared information base. In such circumstances, attention resources cannot be focused to ensure a refined final outcome for the decoding-understanding-interpreting-writing process. The partial, imperfect results at each stage cannot be shaped to feed the others appropriately. At the moment, we do not know what degree of completeness should be achieved at each stage in order to ensure the best results in the overall goal of producing a good translation, and this may well differ according to individual styles. Coordination of the partial products of each subprocess is problematic, and their potential contributions to the overall goal of coming up with a good rendition are often missed or misused, causing mistakes or deviations. In the performance of language tasks such as reading comprehension and writing, these subprocesses do not necessarily interfere with one another to that extent. Through every day 
communicative practices, speakers have grown used to managing rather well the integration of the subroutines underlying listening, speaking, reading and writing. In the case of reading, for instance, the overriding goal is the building of a mental image plus a kind of cognitive frame for a potential future response; in the case of writing, this goal is the structuring of language and textual choices to accurately express the developing mental representation we need to externalize. The specific constraints of translation make the process much more complex.

The intricacy of the translation task and the fact that people do not normally translate in their every day life, unless they live in a completely bilingual environment, has made some authors suggest pedagogical procedures that request text analysis prior to undertaking the translation task (for example, Nord 1988). We feel, however that, despite difficulties, it is better to train future translators in the skills necessary to handle the complexities of the translation task in its entirety. Task management skills that are specific to translation need to be taught and practised, allowing for individual differences. In this way, trainees can learn to make the most of their knowledge resources, develop their language competences and exercise their ability to coordinate their comprehension and writing skills. Thus, they will eventually achieve fast and efficient routines to handle, in an autonomous way, a variety of translation tasks under different types of performance constraints (time, length of text, complexity of subject matter).

The natural ability to translate, apparently shared by every person with some degree of bilingualism, cannot reach the stage of a full developed skill when it is exercised unmonitored or in unstructured task contexts. The result of spontaneous translation is often of poor quality, even when the subjects are proficient in both the native and target languages. The end texts of untrained translators often lack lexical accuracy, stylistic adequacy and pragmatic efficiency, among other problems. Each of the trainees will, however, exhibit different weaknesses and different reasons for such weaknesses. Obviously, language and textual ability is revealed as a crucial factor, for the more limited the language ability, the lower the quality of the natural translation. But language competence, as important as it may be, is not the whole problem. Our understanding of translation begins then by acknowledging the fact that a natural readiness for a translation skill exists as a given; however, we are convinced that to ensure the attainment of professional mastery we need pedagogical manipulation of the task environment tuned to developing problem-solving heuristics of a special kind. This is where self-correction comes in. We focus on the manipulation of the teaching situation in the following paragraphs:

First, in order to have students evaluate the capacity of their ad hoc block, we demand production of a translated text - a "good" translation - regardless of the limitations the students may have. Teachers do so in the belief that this "bad" translation will uncover the students' very specific weaknesses in the language, knowledge and skill competences put to the test by the task. In other words, these poor translations provide the basis for developing the students' awareness of the nature and limitations of their individual ad hoc resources. Second, once the translators have obtained a first general account of the L1 text, they are told to evaluate its quality, identify problems and suggest solutions. They are also told that they will have to justify whatever modifications they introduce to their first draft as a result of revision. The teacher gets a copy of the drafts produced by each of the students and revises them independently, identifying and assessing all problems in them.

Since the students' perception of problems in the revision of the draft text occurs within a frame of message understanding and production, what becomes central are the effects of distortion and inadequacy that erroneous choices of linguistic form cause when students try to create meaningful and appropriate translations. This awareness of the 
interaction between cognitive representations of meaning and linguistic choices, sets up, on an individual basis, the conditions for the search of specific solutions and the evaluation of their contextual effectiveness, committing to memory the new information as a future resource. We believe that it is in this way that the ad hoc block of individual students can be progressively upgraded.

When producing the draft, the students, bearing in mind the non linguistic product of decoding and "make sense" efforts, use this unstable representation to probe the linguistic structures in the $\mathrm{L} 2$ with the purpose of achieving a plausible text. The limited capacity of the short-term memory and the limitation of attention resources probably prevent them from identifying and solving semantic, linguistic, and textual problems. Consequently, they do not have time to reflect on the choices and are unable to work out the best possible solutions. Besides, the task of coordinating the asssociated operations of understanding and writing may not allow them to focus on the stylistic quality of the end product - the translation. Now, at the revision stage, conceived as a training task, they can repeat the operation using the draft version as an extension of their working memory. The critical examination of their own individual externalized output guides them to perceive problems more clearly. Moreover, the additional requirement of having to justify their decisions makes them aware of their responsibility as co-senders of the messages. Also, students realize the need for some kind of meta language to refer to the problems, the proposed solutions, and the meaning and form effects related to each. This requirement helps them to develop resources to communicate effectively with others in their trade.

Research shows clearly that individual translators behave differently in handling problem-solving strategies during performance (Lörscher 1991; Krings 1986; Königs 1987,1988 ). The individual differences in their language competence, their knowledge competence, their individual cognitive styles, and other factors, account for the difficulty in establishing a "standard translation methodology." The effort to produce a methodology that guarantees best results regardless of the type of text and of individual translators has, to this day, been fruitless. We know however that the monitoring of the trainees production does have an effect, and we intend to develop procedures to make such monitoring more effective.

\section{SELF-CORRECTION: AN EXAMPLE}

In what follows we will present a concrete example of the self-correction technique in an actual classroom situation. It is important to mention here that our understanding of the role of the instructor and of peer interaction during sessions coincides with Toury's perception of the role of external environmental feedback in developing in novices the strategic and knowledge competences needed to perform efficiently. We have found particularly relevant the notion of an external monitoring device (Toury 1986) as well as the notions of "process" and "product" monitoring (Faerch and Kasper 1983), and the discussion of the monitoring effect of the presence of expert interpreters [translators] on the performance of an acting one (Anderson 1978).

In our case, all these notions are related to the kind of interactions elicited by the instructors for the self-correction sessions. We believe the kind of processing demanded by these procedures help novices to gradually develop "an internal kind of monitoring mechanism, which can operate on the (interim) product as well as on the production itself" (Toury 1986: 22). 


\section{Source text:}

\section{(A) The 'Bureaucratic Politics'}

Approach: U.S.-Argentine Relations, 1942-47

Ernest R. May

In 1971 Graham T. Allison published a seminal book. In it he developed the thesis that events such as the 1962 U.S.-Soviet crisis over Soviet missile emplacements in Cuba could be explained in three susbstantially different ways, depending on the paradigm of governmental behavior in the back of the explainer's mind.

\section{The Allison Paradigms}

In the first and most widely employed paradigm, the nation figures as a unitary actor. This paradigm underpins many generalizations about politics and (B) political history and nearly all generalizations about international relations. The literature often (B) conflates the nation, the state, the government, the administration, and the chief executive. Some writings deal with a "ruling class" or an ideological entity such as "the Communists" or "the Wall Street imperialists." The logic, however, is the same. A single entity is assumed to be capable of having ideals, perceiving interests, reacting to events, laying plans, having purposes, making decisions, taking actions, and following policies just as might an incorporate individual.

Allison points out that there are at least two alternative paradigms. (C) Underlying one is an assumption that actions of a government are not actions of a nation but rather those of the semiautonomous organizations making up the government. The relatively meager research relevant to this paradigm suggests that even in a (C) well-fitted dictatorship the activities of government are more likely to be products of organizations than reflections of the decisions or purposes of any central mind or minds. The point is developed by Peterson, and, in broader perspective, by Bracher.

Thinking of medieval Europe, we perceive France and the Holy Roman Empire as fictions, the true sovereignties being more localized. In sketching his second paradigm, Allison invites us to think likewise of modern nations, with departments, bureaus, service arms, (A) and the like as counterparts of olden duchies, counties, and cities.

\section{Provisional translation}

(A) LAS POLITICAS BUROCRATICAS

CASO: Las relaciones entre Argentina y los Estados Unidos entre 1942 y 1947

Ernest May

En 1971 Graham T. Allison publicó un libro que tuvo gran repercusión. En él desarrolló la teoría de que los sucesos tales como la crisis de 1962 entre los Estados Unidos y la Unión Soviética sobre el emplazamiento de misiles soviéticos a Cuba podría ser explicada de tres maneras absolutamente diferentes, según sea el paradigma del comportamiento gubernamental que tenga en mente el autor.

Los paradigmas de Allison

En el primer paradigma y el más utilizado, la nación aparece como un actor unitario. Este paradigma defiende muchas generalizaciones sobre la política y la (B) política histórica y casi todas las generalizaciones acerca de las relaciones internacionales. La literatura a menudo (B) conjuga la nación, el estado, el gobierno, la administración y el presidente. Algunos escritos versan sobre una "clase dirigente" o una entidad ideológica tal como son "los Comunistas" o "los Imperalistas de Wall Street". La lógica, sin embargo, es la misma. Se da por sentado que una entidad es capaz de tener ideales, de percibir intereses, de reaccionar a los acontecimientos, de trazar planes, de tener propósitos, de tomar decisiones, de proceder como tal y de seguir las políticas tal como los haría un individuo. 
Allison destaca que existen, al menos, otros dos paradigmas. (C) Suponiendo que el primero es una hipótesis (El primero está sustentado en la hipótesis) de que las acciones de un gobierno no son las acciones de una nación, sino más bien las de organizaciones semiautónomas que conforman el gobierno. La investigación relativamente escasa relacionada con este paradigma propone que incluso en una (C) dictadura sana (bien constituida) es probable que las actividades del gobierno sean producto de las organizaciones más que el reflejo de las decisiones o los propósitos de un poder o poderes centrales. El tema lo desarrolla Peterson, y más en detalle, Bracher. Si nos situamos en la Europa medieval, comprendemos que Francia y el Sacro Imperio Romano son sólo ficciones, porque la verdaderas soberanías estaban más individualizadas. Al trazar su segundo paradigma, Allison nos invita a imaginarnos de la misma manera las naciones modernas: con departamentos, oficinas, servicios armados (A) y lo mismo como contraparte de antiguos ducados, condados y ciudades.

\section{DISCUSSION}

The results of the students' self-correction offer important data on the actual productivity of the development of their competency, not considering the constraints of time and pressure.

Before the self-correction session, students are instructed not only to identify where they went wrong during performance, but also to determine the specific nature of the problems and assess the depth of distortion introduced by their mistaken choices, then they arrange hierarchically their errors according to their gravity. The instructor gives the trainees opportunity to correct only three mistakes in class. Consequently, they need to be very selective, for they will receive negative reactions if, by focussing on trivial issues, major errors go undetected or inproperly assessed at this stage. The instructor demands that the trainees' selections of errors always be substantiated in terms of the distorting effects the errors have introduced into the text. Students take some time to develop the skill and text sensitivity required to assess the gravity of mistakes. The fact that they are expected to defend their choices publicly before the instructor and their classmates gradually stimulates a more effective critical appreciation both of their work and of their skills and resources to handle difficulties.

In the interaction during the self-correction session four different situation types may occur: After a day or two,

A) the trainee fails to detect a problem;

B) the trainee detects a problem, but is either unable to think of solutions for it, or gives solutions that don't work;

C) the trainee detects the problem and uses the correct strategies for solving it;

D) the trainee, when detecting and solving the problem, is able or unable to adequately assess the gravity of the problems identified.

Situation A: In our example, the trainee failed to detect two translation problems, both of which were probably due to lack of knowledge of the source language. Language competence resources did not back up the automatic processing of the ad hoc block. On the other hand, during the revision, the residual block resources were insufficient to alert him to the presence of possible mistakes. (See problems marked with an A in the texts.)

Situation B: In our example, the trainee identified a problem but wrongly interpreted it as "lack of conceptual clarity" instead of perceiving it as "wrong interpretation at the level of a grammatical structure" — premodification of English adjectives — and failed to identify the suffix "-al" as an adjective marker. He said, "There is something unclear 
about the concept of politica histórica, but I'm not sure..." In his residual block he has not developed the routines to flexibly utilize the knowledge of different potential sources of problems to orient the search for solutions.

Also, in this group we had the problem originating in Spanish lexical equivalences for the verb "to conflate." The student was unhappy with the original solution, but was unable to improve it. Again, here we perceive the absence in his residual block of strategies of critical judgement when evaluating the semantic traits embodied in a lexical choice. (See problems marked with a B in the texts)

Situation C: The trainee managed to correctly identify and interpret the problem and was able to find a solution. In the first case in our example, during revision, the student probed new alternatives of meaning for English language configurations including gerunds and, in the light of new information, corrected his first interpretation of the source text. In the second case, the trainee detected that the chosen lexical equivalent did not fit in the context; he then offered an alternative better suited to the concept. In these two cases, the trainee was able to make the best of resources available in the ad hoc and residual blocks. (See problems marked with a $\mathrm{C}$ in the text and the student's corrections in parenthesis.)

Situation D: In our example, the student was able to identify three problems as required by the instructor. Moreover, he provided a fairly adequate assessment of the gravity of the problems detected. The first problem he detected and solved correctly was case No 1 in Situation $C$ where he rightly concluded that the whole paragraph made little sense, and that his translation of the gerund could lead to serious misunderstanding of the whole message. The second problem he detected was case No 2 in Situation $\mathrm{C}$, where he realized that his original choice had introduced a subjective, attitudinal meaning not present in the source text. In his revision, he selected a word that brought the text back to the conceptual and intellectual distinctions the author is addressing. The third problem detected by the trainee was case No 2 in Situation B, where he was able to detect the problem but was not able to produce a good solution. The problem here did not qualify as gravely significant, as there were two other serious problems that went unnoticed. However, the impact of the problem is magnified in the final translation. This illustrates a weakness in the routines for perception and assesment of translation problems in the residual block. These routines are gradually strengthened with proper feedback and practice.

\section{CONCLUSIONS}

By structuring the translation tasks of trainees in several stages of revision and selfcorrection, we lead students to refine a routine of problem identification, evaluation and solution and to set the basis for efficient competence management within the translation specific task. As we said above, we understand translation to be a natural process, yet like other natural processes, including the acquisition of L1 communicative skills, it cannot be fully developed unless it is exercised under critical supervision and monitoring. During the revision stage, the trainee student is confronted with a record of data coming from his own performance. He is led to understand his translation as a text mediating in a communicative event and to analyse its failures accordingly. The text uncovers concrete evidence of meaning problems coming from a number of sources. During the pedagogically structured sessions, the instructor's comments may reward or reinforce negatively the revision skills shown by the student. Also these observations may hint at a variety of unexploited resources to solve the problems identified. These resources might be linguistically based, knowledge-based, strategically based or communicatively based. They might also depend 
on the student's knowledge and ability to apply a repertoire of ready-made routines for translation specific tasks: modulation, transposition, expansion, and so forth.

The teaching of translation needs to design its own procedures to upgrade the performance of trainees. Such a goal cannot be achieved ignoring the psycholinguistic operations underlying the execution of the translation task. However, awareness of the importance of processing is not sufficient unless it can be brought to bear on the concreteness of translated utterances - a linguistic-textual product. The conception of the translation task as resulting from the joint operation of an automatic ad hoc block and a strategic residual block signaling problematic areas and preparing the ground for problem solving strategies, is promising in that it provides a structure for teaching procedures to novices in the field of translation.

The student should at all times feel that he is translating, producing a text within a concrete communicative event. Psychologically, this conscious responsibility acts as a control device for the whole operation in the sense that the student does not lose sight of the general commitment to producing a coherent and undistorted target text that can effectively be directed at the target community. Moreover, self-correction activities develop L1 and L2 competences functionally for translation specific tasks. The students' linguistic resources in each of the languages involved are expanded and consciously correlated in terms of their semantic and pragmatic equivalences. The repertoire of translation devices is expanded and upgraded in a parallel fashion. It is this restructuring of communicative competence and translation procedural competence that accounts for the gradual inclusion of productive knowledge in the automatic execution of the ad hoc routines.

\section{REFERENCES}

BIALYSTOK, E. (Ed.) (1991): Language Processing in Bilingual Children, Cambridge, Cambridge University Press.

DIEGUEZ, M. I. (1990): "Enfoque sicolingüístico de la enseñanza de la traducción: una aplicación práctica", Taller de Letras, 18 , pp. 75-82.

FAERCH, C. and G. KASPER (1987): Introspection in Second Language Research, Clevedon, Philadelphia, Multilingual Matters Ltd.

KÖNIGS, F. (1987): "Psycholinguistische Aspekte des Übersetzens", Assessorato all'istruazione e cultura in lingua italiana (Ed.), Tradurre: teoria ed esperienze, Convegno Internazionale, Bolzano 27/2 28/ 21/3, 1986, Bozen, Educazione Bilingue, XIV, pp. 235-245.

KÖNIGS, F. (1987): "Was beim Übersetzen passiert. Theoretische Aspekte, empirische Befunde und praktische Konsequenzen", Die Neueren Sprachen, 86-2, pp. 162-185.

KÖNIGS, F. (1988): "Aufbruch zu neuen Ufern oder kontinuierliche Weiterentwicklung: Gedanken zu einigen aktuellen Entwicklungen in der (deutschen) Übersetzungswissenschaft", GAL-Bulletin, 9, pp. 63-71.

KRINGS, H. (1986): Was in den Köpfen von Übersetzern vorgeht. Eine empirische Untersuchung zur Struktur des Übersetzungsprozesses an fortgeschrittenen Französischlernern, Tübingen, Narr.

LÖRSCHER, W. (1991): Translation Performance, Translation Process, and Translations Strategies. A Psycholinguistic Investigation, Tübingen, Narr.

MIZON, M. I. (1985): "Code-Breaking Strategies", Seminar on Language for Specific Purposes: A Report, Santiago de Chile.

NORD, Ch. (1988): Textanalyse und Übersetzen, Heidelberg, Groos.

REISS, K. and H. J. VERMEER (1984): Grundlegung einer allgemeinen Translationstheorie, Tübingen.

TOURY, G. (1986): "Natural Translation and the Making of a Native Translator", Textcontext, 1-(b), pp. 11-29. 